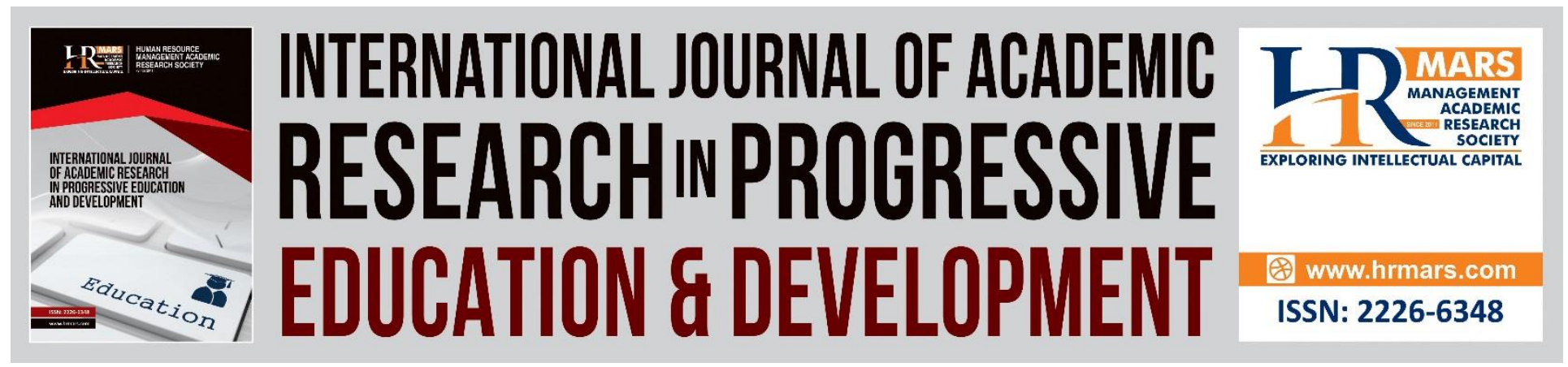

\title{
The Application of Fuzzy Delphi Technique in the Aspect of School Connectedness as Preventive Measure of Preschool Children Delinquency
}

Suziyani Mohamed, Nurul Khairani Ismail, Mohd Isa Hamzah

To Link this Article: http://dx.doi.org/10.6007/IJARPED/v8-i4/6783

DOI:10.6007/IJARPED/v8-i4/6783

Received: 09 November 2019, Revised: 29 November 2019, Accepted: 13 December 2019

Published Online: 31 December 2019

In-Text Citation: (Mohamed et al., 2019)

To Cite this Article: Mohamed, S., Ismail, N. K., \& Hamzah, M. I. (2019). The Application of Fuzzy Delphi

Technique in the Aspect of School Connectedness as Preventive Measure of Preschool Children Delinquency. International Journal of Academic Research in Progressive Education and Development, 8(4), 931-942.

Copyright: (C) 2019 The Author(s)

Published by Human Resource Management Academic Research Society (www.hrmars.com)

This article is published under the Creative Commons Attribution (CC BY 4.0) license. Anyone may reproduce, distribute, translate and create derivative works of this article (for both commercial and non-commercial purposes), subject to full attribution to the original publication and authors. The full terms of this license may be seen

at: http://creativecommons.org/licences/by/4.0/legalcode

Vol. 8(4) 2019, Pg. 931 - 942

http://hrmars.com/index.php/pages/detail/IJARPED

JOURNAL HOMEPAGE

Full Terms \& Conditions of access and use can be found at

http://hrmars.com/index.php/pages/detail/publication-ethics 


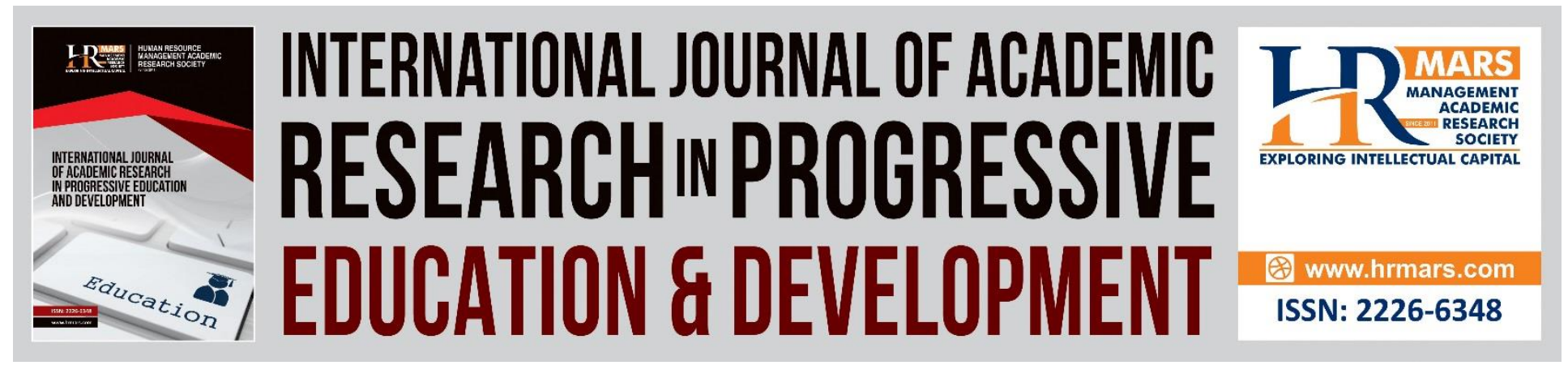

\title{
The Application of Fuzzy Delphi Technique in the Aspect of School Connectedness as Preventive Measure of Preschool Children Delinquency
}

\author{
Suziyani Mohamed, Nurul Khairani Ismail, Mohd Isa Hamzah \\ Faculty of Education, National University of Malaysia, Malaysia \\ Email: isahamzah@ukm.edu.my
}

\begin{abstract}
Connectedness to school is one of the preventative determinants for children's behaviour dilemmas. Hence, this study intends to examine the views and consensus of experts on the need for school-connectedness as a catalyst for preschoolers' behaviour. The research employed design and development research type II design using 11 experts including lecturers and Primary Trainers from Early Childhood Education and Islamic Education selected as research sample using purposive sampling technique. They participated in rating Survey instrument comprising 16 items and was analysed employing the Delphi fuzzy technique template. The study discovered that there is expert consensus on the need for connected with school in promoting positive preschools' behaviour. A sum of 12 items in the dimension of the school environment and classroom management has earned experts' consensus surpassing $75 \%$ and reaching the threshold reading $(\mathrm{d}) \leq 0.2$. Next, the items involved were arranged by rank based on the defuzzification value and improved with some additional items as recommended by the panel of experts
\end{abstract}

Keywords: Expert Consensus, School Connectedness, Fuzzy Delphi Technique, Delinquency, Preschool Children

\section{Introduction}

School connectedness as define by Koivula \& Hanikainen (2017) about relationship among children which provide a feeling of belonging to a community or certain environment. Furthermore, according to Hagerty et al (1993), connectedness has been suggested as one of the ingredients of relatedness. The researchers beforehand defined elements in connectedness to schools are as firmly associated to the school environment as a context / setting (Libbey 2004; Resnick et al. 1997) and focus on personal interactions with people in the school (Blum \& Libbey 2004; Goodenow, 1993; McNeely \& Falci 2004; McNeely, Nonnemaker, \& Blum 2002; Rowe, Stewart, \& Patterson 2007; Wilson, 2004) and both (Bonny et al, 2000; Maddox \& Prinz, 2003). Children can grow better with the guidance of parents, care of teacher and the school atmosphere that enable them to control their behavior (Zakaria et al, 2012). When children start 
entering the school the accelerated development early childhood is enormously impacted by the environment of their daycare and school (Campbell et al., 2016). Hence, it is essential to have the right school environment and classroom management for children, starting to enter the school period and plays one of the factors in preventing behaviour problems among children. By default, childhood period is a stage packed with enthusiasm and delight. But today's digital world is bothering many. Recently, a lot of concerns have emerged that leave a negative impression on the psychology of children growth (Razak et al., 2018). It will result in a negative influence on the mental health and psychological development of the concerned group and contribute to the behavioral dilemmas and causing trauma to these groups due to adverse encounters in the past (Razak et al, 2018). Furthermore, preceding research has revealed that emotional and behavioral obstacles may persist into adulthood if left untreated (Idris, 2017; Ogbiji, 2018; Peprah, 2018)

According to the report of Eager \& Angold (2006), nearly $10 \%$ to $20 \%$ of preschool children exhibit significant levels of impulsivity, hyperactivity, compositionality and aggression. Also, disruptive behavior problems among children like hitting other children, screaming, frequently crying and lack of attention, are correlated with delinquency and failing in school and it needs the attention of all relevant parties (Caspi et al., 2006). Children with this predicament will also have trouble in their transition to schooling (Rimm-Kaufman, Pianta \& Cox, 2000). Previous studies on school connectedness have been conducted extensively in western countries and further studies should be undertaken in non-western countries taking into account factors related to differences in educational systems and local cultural factors (García-Moya et al., 2019). With this gap to consider, the researcher is attempting to view features of connectedness with the school as a context/setting as a factor in countering harmful behaviour of preschoolers through lenses of Islamic perspective from an expert perspective through the fuzzy Delphi method.

\section{Methodology}

The Delphi technique is a technique that has long been used in a study concerning expert opinion (Ridhuan et al, 2014). It is a method based on a group of experts to study and gather ideas to form an agreement on a piece of information. In this section, researcher attempt to discuss on research sample, research instrumen, data collection methods, and data analysis technique.

\section{Research Sample}

In studies using the Fuzzy Delphi technique, the number of experts as respondents in the study was based on Jones and Twiss (1978) who provided that the number of experts in Delphi studies was 10 to 50 experts. The assertion of the number of experts in this method is also in line with the previous study's view that the number of experts allowed is 10 to 15 experts in the event of a high level of expert agreement and uniformity (Adler \& Ziglo, 1996). In this study, the total number of experts involved was 11 and these experts consisted of the following criteria: lecturers and primary trainers in the field of early childhood education and Islamic education.

\section{Research Instrument}


Vol. 8, No. 4, 2019, E-ISSN: 2226-6348 @ 2019 HRMARS

This study used the Fuzzy Delphi technique to gain expert consensus on school connectedness on items developed. The items were developed based on the findings from phase 1 previously. Phase 1 of the study was completed by using need analysis through teacher interview on the need of school connectedness in fostering preschool child attitude and related literature studies. This paper does not discuss the earlier findings of this study but instead focuses on the outcomes from the use of the Fuzzy Delphi technique analysis. The questionnaire comprises two dimensions of school connectedness which is school environment and classroom management. Here are the items provided to the study experts $t$ as shown in the Table 1.

Table 1 Questionnaire given to the experts

\begin{tabular}{ll}
\hline SCSE1 & \multicolumn{1}{c}{ Dimension of School Environment } \\
SCSE2 & $\begin{array}{l}\text { Clean and pleasant } \\
\text { Lives students a sense of security } \\
\text { SCSE3 }\end{array}$ \\
SCSE4 & $\begin{array}{l}\text { Posing and supportive } \\
\text { Has a mentor-mentee program }\end{array}$ \\
SCSE5 & Stresses the concept of muraqabah that God is always observing \\
SCSE6 & Encourages student involvement in community activities \\
SCSE7 & Emphasises the idea of Ihsan in students \\
SCSE8 & \multicolumn{1}{c}{ Dimensions of Class Management } \\
\hline SCCM1 & Well taken care of by the teacher \\
SCCM2 & Has clear routines and guidelines \\
SCCM3 & Fairness in student behaviour management \\
SCCM4 & Allows students to build influence \\
SCCM5 & Promotes a culture of respect among students \\
SCCM6 & Helps students to make decisions about class activities \\
SCCM7 & Has a small number of students per class \\
SCCM8 & Encourages students to express their views on something \\
\hline
\end{tabular}

\section{The Data collection method and Analysis Technique}

As a step to implement the Fuzzy Delphi technique in this study, the researcher first defined and collected the items produced through the findings of Phase I in a proper form that could be mastered by a panel of experts. During the Fuzzy Delphi study, the experts interacted with the questionnaire items by identifying their level of agreement on each item, reducing, adding, and purifying the item if they thought it was necessary. The items tested their validity in terms of content validity which involved the process of establishing statements, using language that matched the educational language and clarity of purpose for each item through a seven-point Likert scale that reflected their level of agreement (Ridhuan et al, 2014). The data from the Likert Scale were translated into Fuzzy number data and analyzed using Excel software. This data analysis technique is known as the Fuzzy Delphi technique or the Fuzzy Delphi Method (FDM). Expert comments and suggestions are also taken into account to improve existing items.

There are two essential characters in the Fuzzy Delphi technique, namely the Triangular Fuzzy Number and the Defuzzification process. The data analysis process started by preparing 
Vol. 8, No. 4, 2019, E-ISSN: 2226-6348 @ 2019 HRMARS

the triangular fuzzy number by arranging the values of $m 1, m 2$ and $m 3$. The value of $m 1$ represents the minimum value; then the value $m 2$ represents the reasonable value, whereas value $\mathrm{m} 3$ signifies the maximum value. Triangular Fuzzy Number is employed to create the Fuzzy scale (similar to the Likert scale) to translate the linguistic variable to the fuzzy number. The level of agreement for the Fuzzy scale comes in odd number. The higher the Fuzzy scale, the more precise the data obtained. (Ridhuan et al, 2014) For this study, the researcher used a seven-point fuzzy scale, as shown in Table 2.

Table 2 Seven- point fuzzy scale

\begin{tabular}{cc}
\hline Agreement Level Table & Fuzzy scale \\
\hline Strongly Disagree & $(0.0,0.0,0.1)$ \\
Totally disagree & $(0.0,0.1,0.3)$ \\
Disagree & $(0.1,0.3,0.5)$ \\
Not sure & $(0.3,0.5,0.7)$ \\
Agree & $(0.5,0.7,0.9)$ \\
Totally Agree & $(0.7,0.9,1.0)$ \\
Strongly Agree & $(0.9,1.0,1.0)$ \\
\hline
\end{tabular}

As a step to obtain experts' consensus on every item, the threshold value should not be more than 0.2 . The percentage of experts' consensus needs to be more than the amount of $75 \%$, whereas the defuzzification value for every item has to be more than the $\alpha$-cut value $=0.5$. To get the threshold value, the location between two fuzzy numbers determine by formula as below;

$$
\mathrm{d}(\overline{\mathrm{m}}, \overline{\mathrm{n}})=\sqrt{\frac{1}{3}\left[\left(\mathrm{~m}_{1}-\mathrm{n}_{1}\right)^{2}+\left(\mathrm{m}_{2}-\mathrm{n}_{2}\right)^{2}+\left(\mathrm{m}_{3}-\mathrm{n}_{3}\right)^{2}\right]}
$$

If the $d$ value $\leq 0.2$, it signifies that all the experts have reached a consensus towards the item. Otherwise, the second round has to be done to see if the item is needed or not (Chen, 2000; Cheng \& Lin, 2002). Fuzzy Delphi technique also includes the process of determining the consensus of the experts, whether exceeding or equals to $75 \%$ for the entire dimensions of every item. Every item is assumed to have reached the experts' consensus if the percentage of the agreement for the items is identical or is exceeds 75\% (Chu \& Hwang, 2008; Murray \& Hammons, 1995). The defuzzification process was also done in the data analysis process in the Fuzzy Delphi technique. It is the process of determining the position or rank of every item or determining the position of every variable or sub-variable.

Next, the $\alpha$-cut value $=$ the median value for ' 0 ' and ' 1 ', where $\alpha$-cut $=(0+1) / 2=0.5$. If the value of $A$ yielded is less than the $\alpha$-cut value $=0.5$, the item will be rejected because it shows the agreement of the experts in rejecting the item. Still, if the value of $A$ exceeds the $\alpha$-cut value= 0.5 , the item will be accepted because it presents experts' consensus to accept the item (Mohd Ridhuan et al, 2014). The data were then tabulated to get the Fuzzy value (n1, n2, n3) also the Fuzzy average value $(\mathrm{m} 1, \mathrm{~m} 2, \mathrm{~m} 3)$ to obtain the threshold value, the percentage of experts' consensus, the defuzzification value and the item ranking. 
Vol. 8, No. 4, 2019, E-ISSN: 2226-6348 @ 2019 HRMARS

\section{Study Finding}

The conclusions confirm the expert agreement and the priority between dimensions through the value of $d$ dimensions, the percentage of expert consensus on each dimension. Whereas expert consensus on an item is seen through the value of $d$ item, the percentage of expert consensus on the item. While the rank of the item in each dimension is regarded from and the item in each dimension is viewed through the item's score (defuzzification).

\section{School Environment}

The table presents the expert consensus and ranking of items for school environment dimensions. The data consisted of the $d$ value of each item, the $d$ value of each dimension, the percentage of expert agreement for each item, the percentage of expert agreement for the dimension, item score value and item rank. The final items and it's rank for this dimension are shown in Table 3.

Table 3 The final items and it's rank for school environment dimensions.

\begin{tabular}{|c|c|c|c|c|c|c|c|c|c|}
\hline $\begin{array}{l}\text { Dimens } \\
\text { ion }\end{array}$ & Code & Item & $\begin{array}{c}\mathrm{D} \\
\text { item }\end{array}$ & $\begin{array}{c}\% \\
\text { consen } \\
\text { sus } \\
\text { (item) } \\
\end{array}$ & $\begin{array}{c}\text { Defuzzifi } \\
\text { cation } \\
\text { value }\end{array}$ & $\begin{array}{l}\text { Item } \\
\text { rank }\end{array}$ & $\begin{array}{c}\text { Expert } \\
\text { consensus }\end{array}$ & $\begin{array}{c}\mathrm{D} \\
\text { Dimens } \\
\text { ion }\end{array}$ & $\begin{array}{l}\% \text { consensus } \\
\text { (Dimension) }\end{array}$ \\
\hline \multirow{8}{*}{$\begin{array}{l}\text { School } \\
\text { environ } \\
\text { ment }\end{array}$} & SCSE1 & $\begin{array}{l}\text { Clean and } \\
\text { pleasant }\end{array}$ & 0.025 & $100 \%$ & 0.958 & 3 & Accepted & \multirow{8}{*}{0.134} & \multirow{8}{*}{$76 \%$} \\
\hline & SCSE2 & $\begin{array}{l}\text { Gives students } \\
\text { a sense of } \\
\text { security }\end{array}$ & 0.000 & $100 \%$ & 0.967 & 1 & Accepted & & \\
\hline & SCSE3 & $\begin{array}{l}\text { Loving and } \\
\text { supportive }\end{array}$ & 0.000 & $100 \%$ & 0.967 & 1 & Accepted & & \\
\hline & SCSE4 & $\begin{array}{l}\text { Positive and } \\
\text { respectful }\end{array}$ & 0.045 & $100 \%$ & 0.948 & 4 & Accepted & & \\
\hline & SCSE5 & $\begin{array}{l}\text { Has a mentor- } \\
\text { mentee } \\
\text { program }\end{array}$ & 0.371 & $18 \%$ & 0.806 & 7 & Rejected & & \\
\hline & SCSE6 & $\begin{array}{l}\text { Stresses the } \\
\text { concept of } \\
\text { muraqabah } \\
\text { that God is } \\
\text { observing }\end{array}$ & 0.131 & $91 \%$ & 0.906 & 6 & Accepted & & \\
\hline & SCSE7 & $\begin{array}{l}\text { Encourages } \\
\text { student } \\
\text { involvement } \\
\text { in community } \\
\text { activities }\end{array}$ & 0.372 & $9 \%$ & 0.773 & 8 & Rejected & & \\
\hline & SCSE8 & $\begin{array}{l}\text { Emphasises } \\
\text { the idea of } \\
\text { Ihsan in } \\
\text { students }\end{array}$ & 0.127 & $100 \%$ & 0.900 & 5 & Accepted & & \\
\hline
\end{tabular}

For dimensions of the school environment, the threshold value (d) is $\leq 0.2$, which is 0.134 . The expert panel approval percentage also indicated that the entire item exceeded the $75 \%$ value 
of $76 \%$. It means that the experts have satisfied this dimensions. All items had a threshold value of $(d) \leq 0.2$ and had expert's agreement percentage of over 75\% except for SCSE 5 and SCSE items 7. Findings analysis revealed SCSE 5 items with d values $(0.371)$ with a percentage (18\%) of expert and item agreement SCSE 7 with a value of $d(0.372)$ with a percentage (9\%) were rejected. It is because they did not meet the item preference criteria based on a fuzzy triangular numbering associated with a value of $\leq 0.2$ and expert's agreement of more than $75 \%$ (Mohd Ridhuan et al., 2014). Meanwhile, based on Table 4, the item 'Loving and Supportive' is on the first rank, followed by 'Gives students a sense of security' and followed by another items in the dimension of the school environment.

\section{Classroom Management}

The table presents the expert consensus and ranking of items for classroom management dimensions. The data consisted of the $d$ value of each item, the $d$ value of each dimension, the percentage of expert agreement for each item, the percentage of expert agreement for the dimension, item score value and item rank. The final items and it's rank for this dimension are shown in Table 4.

Table 4 The final items and it's rank for classroom management dimensions. 
INTERNATIONAL JOURNAL OF ACADEMIC RESEARCH IN PROGRESSIVE EDUCATION AND DEVELOPMENT

Vol. 8, No. 4, 2019, E-ISSN: 2226-6348 @ 2019 HRMARS

\begin{tabular}{|c|c|c|c|c|c|c|c|c|c|}
\hline $\begin{array}{l}\text { Dimen } \\
\text { sion }\end{array}$ & Code & Item & $\begin{array}{c}\mathrm{D} \\
\text { item }\end{array}$ & $\begin{array}{c}\% \\
\text { conse } \\
\text { n-sus } \\
\text { (item) }\end{array}$ & $\begin{array}{l}\text { Defuzzi } \\
\text { ficatio } \\
\mathrm{n} \text { value }\end{array}$ & $\begin{array}{l}\text { Item } \\
\text { rank }\end{array}$ & $\begin{array}{c}\text { Expert } \\
\text { consensus }\end{array}$ & $\begin{array}{c}\mathrm{D} \\
\text { Dime } \\
\mathrm{n}- \\
\text { sion }\end{array}$ & $\begin{array}{l}\% \text { consensus } \\
\text { (Dimension) }\end{array}$ \\
\hline & $\begin{array}{l}\text { SCCM } \\
1\end{array}$ & $\begin{array}{l}\text { Well taken } \\
\text { care of by } \\
\text { the teacher }\end{array}$ & $\begin{array}{c}0.09 \\
2\end{array}$ & $91 \%$ & 0.924 & 4 & Accepted & & \\
\hline & $\begin{array}{l}\text { SCCM } \\
2\end{array}$ & $\begin{array}{l}\text { Has clear } \\
\text { routines } \\
\text { and } \\
\text { guidelines }\end{array}$ & $\begin{array}{c}0.08 \\
1\end{array}$ & $91 \%$ & 0.933 & 1 & Accepted & & \\
\hline & $\begin{array}{l}\text { SCCM } \\
3\end{array}$ & $\begin{array}{l}\text { Fairness in } \\
\text { student } \\
\text { behaviour } \\
\text { manageme } \\
\text { nt }\end{array}$ & $\begin{array}{c}0.08 \\
1\end{array}$ & $91 \%$ & 0.933 & 1 & Accepted & & \\
\hline & SCCM & Allows & 0.33 & $36 \%$ & 0.764 & 8 & Rejected & & \\
\hline $\begin{array}{l}\text { Class- } \\
\text { room }\end{array}$ & 4 & $\begin{array}{l}\text { students to } \\
\text { build } \\
\text { influence }\end{array}$ & 7 & & & & & 0.153 & $77 \%$ \\
\hline $\begin{array}{l}\text { Mana- } \\
\text { geme } \\
\text { nt }\end{array}$ & $\begin{array}{l}\text { SCCM } \\
5\end{array}$ & $\begin{array}{l}\text { Promotes a } \\
\text { culture of } \\
\text { respect } \\
\text { among } \\
\text { students }\end{array}$ & $\begin{array}{c}0.17 \\
2\end{array}$ & $91 \%$ & 0.870 & 6 & Accepted & & \\
\hline & SCCM & Helps & 0.07 & $100 \%$ & 0.930 & 3 & Accepted & & \\
\hline & 6 & $\begin{array}{l}\text { students to } \\
\text { make } \\
\text { decisions } \\
\text { about class } \\
\text { activities }\end{array}$ & 1 & & & & & & \\
\hline & $\begin{array}{l}\text { SCCM } \\
7\end{array}$ & $\begin{array}{l}\text { Has a small } \\
\text { number of } \\
\text { students } \\
\text { per class }\end{array}$ & $\begin{array}{c}0.09 \\
2\end{array}$ & $91 \%$ & 0.924 & 4 & Accepted & & \\
\hline & $\begin{array}{l}\text { SCCM } \\
8\end{array}$ & $\begin{array}{l}\text { Encourages } \\
\text { students to } \\
\text { express } \\
\text { their views } \\
\text { on } \\
\text { something }\end{array}$ & $\begin{array}{c}0.29 \\
9\end{array}$ & $27 \%$ & 0.806 & 7 & Rejected & & \\
\hline
\end{tabular}

For classroom management dimensions having a threshold value (d) $\leq 0.2$ is 0.153 . The 
expert panel approval percentage also indicated that the entire item exceeded the $75 \%$ value of $77 \%$. It means that the experts have reached this dimensions. All items had a threshold value of (d) $\leq 0.2$ and had an expert agreement percentage of over $75 \%$ except for items 4 and 8 . Findings analysis showed that item SCCM 4 had a value of $d(0.337)$ with a percentage $(36 \%)$ of expert agreement and item SCCM 8 with a d value (0.299) with a percentage (27\%) and were rejected. It is because they did not meet the criteria for accepting items based on a fuzzy triangular numbering associated with a value of $\leq 0.2$ and expert's agreement of more than $75 \%$ (Mohd Ridhuan et al., 2014). The items arranged by priority are as illustrated in Table 6. Meanwhile, based on Table 6, the item 'Has clear routines and guidelines' is on the first rank, followed by 'Fairness in student behavior management' and followed by another items in the dimension of classroom management.

\section{Discussion of the Findings}

Social, cognitive, and behavioral development of children is influenced by school and classroom factors (O'Brennana, Bradshawa \& Furlong, 2014; Jimerson \& Furlong, 2006). The findings of this study show that classroom management dimensions take precedence over the first place over the dimensions of the school environment according to expert views.

The dimensions of the school environment become the priority over the dimensions after the classroom management dimension. The school as a whole is a safe place for children to live, but it can sometimes be a place where students are exposed to immoral activity and become victims of such conditions (Graham et al, 2009). Feeling safe in the social, emotional, intellectual and physical aspects is a basic human need and the feelings present in this school environment can help children in their learning and healthy development (Devine \& Cohen, 2007). According to the study of safety in the school, the environment can be enhanced by promoting good relationships such as mutual respect among school children (Cowie et al, 2002; Naylor \& Cowie, 1999).

From an Islamic perspective, school management should inculcate and foster moral values in their morals so that they feel secure and strive for God's blessings (Rosnani, 1998). Part of this culture is muraqabah in nature and that means that God is always watching over their actions and will be held accountable (Makhsin et al, 2019) and the concept of ihsan, which means doing something in the best way (proficiency) (Othman Alhabsyi, 1998). Should every party of the school appreciate these values, the school environment will be safer for the students. This concept is not so different from the idea of schools relating to "witness-related" behaviors. It is present in the researches by Fonagy et al (2005) that were able to reduce bullying activities in the prevention program.

Next, the classroom climate is a compilation of factors including social interactions between students and teachers, behavioral and academic expectations, as well as the physical environment of the classroom (Mainhard et al, 2011). Clear routines in managing practices such as the use of rewarding techniques such as other praise may promote the development of children's good behavior (Epstein et al, 2008; Koth, Bradshaw, \& Leaf, 2008). When the teacher well administers the classroom, it creates a positive relationship between the students and the student and the teacher and makes them more active in the learning session. Also, teachers who promote a culture of respect and counselling with students will create a safe environment and 
increase the level of intimacy among students by reducing the likelihood of unintended situations such as mocking and embarrassing other students (Ryan \& Patrick, 2001). Also, the small number of students per class can foster closer relationships between them and teachers and it creates a better impact on students as teachers can focus more on each student. (McNeely, Nonnemaker \& Blum, 2002). Teachers also reported that children from these classrooms were better at socializing with friends, more friendly and less problematic in terms of behavior. (Early Child Care Research Network, 2004).

\section{Conclusion}

In conclusion, it clearly shows that the need for children to be brought up in a great school environment together with necessary attention of aqeedah elements in addition to the physical aspects as highlighted by western scholars. The school's top management and teachers need to cooperate in making this agenda prosperous. Other than that, the factor of good classroom management by teachers play an essential role in fostering positive children's behavior. Teachers need to promote positive peer behaviors and celebrate pupils as children. The mastery of children's developmental psychology is also one of the best techniques for developing activities and lessons to be useful in making this impact.

\section{Acknowledgement}

This research was supported by the grant from the Universiti Kebangsaan Malaysia GG-2019-003 and GG2019-059.

\section{Corresponding Author}

Mohd Isa Hamzah

Faculty of Education, National University of Malaysia, 43600 UKM, Bangi Selangor.

Email: isahamzah@ukm.edu.my

\section{References}

Adler, M., \& Ziglio, E. (1996). Gazing into the oracle: The Delphi method and its application to social policy and public health. London: Jessica Kingsley Publishers.

Campbell, B. S., Denham, A. S., Howarth, Z. G., Jones, M. S., Jessica, V., Williford, P. A., Willoughby, T. M., Yudron, M., \& Darling-churchill, K. (2016). Commentary on the Review of Measures of Early Childhood Social and Emotional Development : Conceptualization , Critique, and Recommendations. Journal of Applied Developmental Psychology 45,19-41.

Caspi, A., Moffitt, T. E., Newman, D. L., \& Silva, P. A. (1996). Behavioral observations at age three years predict adult psychiatric disorders: Longitudinal evidence from a birth cohort. Archives of General Psychiatry, 53, 1033-1039.

Chang, P. L., Hsu, C. W., \& Chang, P. C. (2011). Fuzzy Delphi method for evaluating hydrogen production technologies. International Journal of Hydrogen Energy, $14172-14179$.

Chen, C. T. (2000). Extensions of the TOPSIS for group decision-making under fuzzy environment. Fuzzy Sets and Systems 2000, 114: 1-9. 
Vol. 8, No. 4, 2019, E-ISSN: 2226-6348 @ 2019 HRMARS

Cheng, C. H., \& Lin, Y. (2002). Evaluating the best main battle tank using fuzzy decision theory with linguistic criteria evaluation. European Journal of Operational Research 2002, 142(1), 74-86.

Chu, H. C., \& Hwang, G. J. (2008). A Delphi-based approach to developing expert systems with the cooperation of multiple experts. Expert Systems with Applications 2008, 34(28), 26-40.

Cowie, H., Naylor, P., Talamelli, L., Chauhan, P., \& Smith, P. K. (2002). Knowledge, use of and attitudes towards peer support. Journal of Adolescence, 25, 453-467.

Devine, J., \& Cohen, J. (2007). Making your school safe: Strategies to protect children and promote learning. New York, NY: Teachers College Press.

Eager, H. L., \& Agnold, A. (2006). Common emotional dan behavioural disorder in preschool children: presentation, nosology and epidemiology. Journal of Child Psychology and Psychiatry, 47 (3), 313-337.

Early Child Care Research Network. (2004). Does class size in first grade relate to children's academic and social performance or observed classroom processes? Developmental Psychology, 40(5), 651-664.

Epstein, M., Atkins, M., Cullinan, D., Kutash, K., \& Weaver, R. (2008). Reducing behaviour problems in the elementary school classroom: A practice guide. Washington, DC: National Centre for Education Evaluation and Regional Assistance, Institute of Education Sciences, U.S. Retrieved from http://ies.ed.gov/ncee/wwc/publications/ practiceguides.

Fonagy, P., Twemlow, S. W., Vemberg, E. M., Sacco, F. C., \& Little, T. D. (2005). Creating a peaceful school learning environment: The impact of an anti-bullying program on educational attainment in elementary schools. Medical Science Monitor, 2, 317-325.

García-Moya, I., Bunn, F., Jiménez-Iglesias, A., Paniagua, C., \& Brooks, F. M. (2019). The conceptualisation of school and teacher connectedness in adolescent research: a scoping review of literature. Educational Review, 71(4), 423-444.

Graham, S., Bellmore, A., Nishina, A., \& Juvonen, J. (2009). "It must be me": Ethnic diversity and attributions for peer victimization in middle school. Journal of Youth and Adolescence, 38(4), 487-499.

Idris, I. B. (2017). Emotional and Behavioural Problems among Children: Issues and Trends in Malaysia. International Journal of Public Health Research, 7(2), 829-835

Jimerson, S. R., \& Furlong, M. J. (2005). Handbook of school violence and school safety: From research to practice. New York, NY: Routledge.

Jones, H., \& Twiss, B. L. (1978). Forecasting Technology for Planning Decisions. New York: Macmillan.

Koth, C. W., Bradshaw, C. P., \& Leaf, P. J. (2008). A multilevel study of predictors of student perceptions of school climate: The effect of classroom-level factors. Journal of Educational Psychology, 100, 96-104.

Mainhard, M. T., Brekelmans, M., Brok, P., \& WubbelS, T. (2011). The development of the classroom social climate during the first months of the school year. Contemporary Educational Psychology, 36, 190- 200.

Makhsin, M., Noor, N. F. M., Ismail, N., Bohari, A. M., Amirul \& Sukeri, F. M. (2019). Journal of self-hisbah reflection: Islamic innovation and creativity in increasing adolescent religiosity and resilience. International Journal of Innovative Technology and Exploring Engineering, 
$8(7), 61-66$.

McNeely, C. A., Nonnemaker, J. M., \& Blum, R. W. (2002). Promoting school connectedness: evidence from the National Longitudinal Study of Adolescent Health. Journal of School Health, 72(4), 136-146.

Mohd. Ridhuan, M. J., Zaharah, H., Rabihah, N. M. N., Arifin, A. S. (2014). Pengenalan Asas Kaedah Fuzzy Delphi Dalam Penyelidikan Rekabentuk Pembangunan. Bangi: Minda Intelek.

Naylor, P., \& Cowie, H. (1999). The effectiveness of peer support systems in challenging school bullying: the perspectives and experiences of teachers and pupils. Journal of Adolescence, 22, 467-479.

O’Brennana, M. L., Bradshawa, P. C., \& Furlong, J. M. (2014). Influence of Classroom and School Climate on Teacher Perceptions of Student Problem Behavior. School Ment Health, 8(2), 125-136.

Osterman, K. F. (2010). Teacher practice and students' sense of belonging. Dordrecht, The Netherlands: Springer.

Razak, N. H. A., Johari, K. S. K., Mahmud, M. I., Zubir, N. M., \& Johan, S. (2018). General Review on Cognitive Behavior Play Therapy on Childrens' Psychology Development. International Journal of Academic Research in Progressive Education and Development, 7(4), 134-147.

Rimm-Kaufman, S. E., Pianta, R. C., \& Cox, M. J. (2000). Teachers' judgments of problems in the transition to kindergarten. Early Childhood Research Quarterly, 15, 147-16.

Rosnani, H. (1998). Pengurusan pendidikan untuk sekolah daripada perspektif Islam. Prosiding Seminar Pendidikan Guru Untuk Sekolah Berkesan, 62-63.

Ryan, A. M. \& Patrick, H. (2001). The classroom social environment and changes in adolescents' motivation and engagement during middle school. American Educational Research Journal, 38(2), 437-46.

Al-Habshi, O. S. (1998). Management Ethics' dalam Islamic Management for Excellence Revitalizing People for the Future. Kuala Lumpur: Institut Perkembangan Minda.

Stapa, Z., Ismail, A. M., \& Yusuf, N. (2012). Faktor Persekitaran Sosial Dan Hubungannya Dengan Pembentuka Jati Diri. Jurnal Hadhari Special Edition, 155-172.

Ogbiji, J. E. (2018). A Comparative Study of the Administrative Effectiveness of Principals of Public and Private Secondary School in Cross River State, Nigeria. International Journal of Academic Research in Progressive Education and Development, 7(4), 427-434.

Peprah, W.K. (2018). Predictive Relationships among the Elements of the Fraud Diamond Theory: The Perspective of Accountants, International Journal of Academic Research in Accounting, Finance and Management Sciences 8 (3): 141-148. 